\title{
THE INTERRELATION OF PETROGRAPHICAL PROPETIES OF ROCKS AND THEIR CRUSHING AND GRINDIG FEATURES: A LITERATURE REVIEW
}

\author{
Izabella Rebeka Márkus \\ PhD student, University of Miskolc, Institute of Raw Material Preparation and Environmental Processing \\ 3515 Miskolc, Miskolc-Egyetemváros, e-mail: ejtmir@uni-miskolc.hu
}

\begin{abstract}
The energy consumed in the process of comminution highly depends on the mechanical properties of the materials being ground, which is controlled by the constituent minerals, their relative abundance and the texture. The quantitative description of textural information is essential in determining which textural characteristics can be attributed to certain mineral processing behaviours. The researchers' opinions on the effect of different textural elements on the grindability differ. A correlation which can attribute numerical crushability and grindability values to certain textural features have not been established yet, however some general conclusions can be drawn. The effect of the mineralogical constitution is negligible, but the variation in hardness and the texture has a great impact.
\end{abstract}

Keywords: petrographical properties, texture, grindability

\section{Introduction}

Comminution is a process in which larger pieces of ore or rock are subjected to mechanical forces, as a result, there is a change in the dispersed state of solids. There are many reasons for using comminution: attaining certain grain size and grain shape, liberation of useful minerals, increasing the grain surface and thus its reactivity, changing structural and chemical characteristics, etc. The comminution process, which includes both crushing and grinding, is one of the world's most energy-intensive industrial processes, it accounts around 50 percent of a mine's energy consumption and 10 percent of total production costs. Mineral processing plants are being designed and operated at less than optimal energy efficiency [1], because, especially in the past, the goal was to obtain a certain particle size regardless of the efficiency of energy use.

The energy consumed in the process of comminution depends on both the mechanism of comminution and the mechanical properties of the materials being ground [2]. Energy consumption during crushing is related to the rock strength, which is controlled by the constituent minerals of the rock, relative mineral abundances, texture, fracture frequency, and its associations [3, 4]. The effect of rock properties like mineralogy, texture and structure on the grindability and crushability is a widely researched topic in the international literature. With the "greening" of mining operations not only rising energy costs, but also the accompanying $\mathrm{CO}_{2}$ emission are reasons for the resource industries to look for smarter solutions, particularly for the energy-intensive comminution processes [2]. In the field of ore processing geometallurgy is becoming a tool for this purpose. Geometallurgy combines geological and metallurgical information to create spatially-based predictive model for mineral processing plants, a practical amalgamation of ore geology and minerals processing [5]. The data obtained from the observation of mineralogical and textural properties are used as input data for the modelling and the prediction of energy consumption of comminution processes. There are also some attempts in the field of coal processing to link 
texture and mineral matter content to grinding properties [6]. In the field of non-metallic minerals and aggregate production there are only a few scarce studies regarding the effect of rock properties, like mineralogy, texture, and structure on their comminution properties.

This paper aims to give a review on the different rock textural and structural properties, and their effect on the comminution process.

\section{Rock structure and texture}

Rocks are complex and heterogeneous materials, their properties are defined by the mineral composition, and their texture and/or structure. The term structure is mostly used just by the geologists and refers to individual, contrasted, large-scale features, like depositional and deformational structures, igneous features, which gives information about the forming condition. Texture refers to a general description of the small-scale properties which mostly is in qualitative terms [7] which makes it difficult to describe it quantitatively. There is a lack of a coherent definition for the term 'texture' between geologists, mineral processors and metallurgists [8], and even in the field of mineral processing a coherent definition non-existant. Wills and Napier-Munn [9], Hilde and Powell [10] define texture as the mineralogical composition, grain size and size distribution, grain shape and orientation, shape distribution, irregularity of the grain boundaries, spatial distribution of the grains, and associations between minerals. Petruk [11], Yildirim [4], Dominy [12] complement this with the grain boundary relationships, fractures and veinlets. Popov et al. [2] differentiate rock texture and structure. In their definition the texture of a rock is the term used to describe the nature of its composition by individual components, defined by the form of the individual mineral components and their mutual geometric relationships, notedly the grain shape and grain size of the mineral components, while the structure is defined as the spatial arrangement of its components. As it can be seen there is not a one-size-fits-all description for the term texture. The definitions are typically variable, and in the field of mineral processing it is not uncommon that texture only refers to the attributes that are likely to affect the processes of liberation, flotation and ultimately the recovery of the mineral phase of interest. The texture is of high importance in evaluation of the mechanical properties of rocks and gives an idea about the mechanism for the formation of rock fabrics and also controls the anisotropic physical properties of rocks [13].

\section{Methods used for the observation and quantification of textural information}

Within the mining industry, it is well known that characteristics of texture can cause variability in mineral processing behaviour [8]. The descriptive nature of textural information can make it difficult to quantify and establish which textural attributes can be related to certain mineral processing behaviours. A profound knowledge of the mineral behaviour is required, the understanding of textural features on a microscopic level is essential for an efficient comminution process and for the modelling and simulation of comminution processes. The increased focus on the micro-textural features led to the development of numerous optical microscopy- and electron microscopy-based methods.

The Quantitative Microstructural Analysis (QMA) is a collective term for numerous methods for analysing the geometry and mechanical properties of microstructural constituents. It is an optical microscopy-based method carried out on three perpendicular thin or polished sections extracted from the same rock specimen. Rock forming minerals and rock microstructure are described with the help of a polarizing optical microscope, assessed by various stereological methods, then a mathematical method is used to characterize the rocks quantitatively, based on the calculation of relevant structural and textural characteristic data [14]. The most important rock characteristics mathematically derived in the form 
of characteristic values are mode (volume percentage of the mineral phase), grain size, grain shape, roughness, orientation, distribution, and space filling.

Another optical microscopy-based method is the determination of texture coefficient (TC). This method is used especially in studies which aims to link textural and structural features with strength characteristics of rocks. Texture coefficient is a comprehensive and reliable index to quantify the texture of a rock. A thin section is prepared from the material of interest on which photographs are captured and on the photograph the perimeter and area, the large and small diameters of each grain are determined, from which the aspect ratio (which is the length to diameter ratio), form factor, aspect ratio of grains (the ratio of the large diameter and small diameter of the grain) and the angle factor are calculated, and these parameters are used to calculate the texture coefficient $[15,16]$.

The determination of average grain size index (AGSI) is another optical microscopy-based method, in which on a photograph of a thin section the textural properties like the grain size and distribution are determined. From the textural definition of samples, the average grain size index can be calculated according to the following

$$
A G S I=\frac{1}{100} \sum_{k=1}^{n} P_{k}
$$

where AGSI is the average grain size index; $\mathrm{P}$ is the total percentage of grain size and $\mathrm{k}$ is the number of the classification interval [13].

Automated Scanning Electron Microscopy (ASEM) systems are widespread and routinely applied in the mining industry [17]. These methods provide fast and reliable quantification of the mineralogy and texture, of which the two most prominent are the Quantitative Evaluation of Mineralogy by Scanning electron microscope (QEMSCAN ${ }^{\circledR}$ ) system and the Mineral Liberation Analyzer (MLA) system. In the case of both, the digital mineral images are realised with the use of backscattered electrons (BSE) and energy dispersive X-ray spectra (EDS). The difference lies in the measurement technique and data processing. In the case of the QEMSCAN, the minerals are identified based on their X-ray element-spectra and the BSE brightness is used to distinguish the particle from the surroundings. In the case of MLA, the BSE brightness is used to define the particles which subsequently are classified by one X-ray spectrum per particle $[17,18]$. The QEMSCAN is suitable for the quantitative chemical measurement of individual mineral grains and the generation of mineral maps, while the MLA is suitable for the identification of minerals and mineral aggregates, and the quantification of mineral abundance, particle size and liberation.

Computed tomography (CT) provides a mechanism for non-destructive studies of three-dimensional properties of rocks and it is used in earth sciences including geology, mineralogy, petroleum, mineral processing, mechanical and civil engineering purposes. It is a method suited for the definition of porosity, fracturing, cavities and their distribution by diameter, volume, sphericity degree and microtomography can be applied in the measurement of mineral phases with equal X-ray density throughout the whole sample. The method uses an X-ray beam signal that is a function of the incident X-ray energy and the linear attenuation coefficient, which is proportional to the mean local density of the particle [4]. During scanning the sample is rotated around a vertical axis by $180^{\circ}$ with certain steps. A detector is placed on the opposite side of the sample to the X-ray source and detects the X-ray absorption by the object at a given point and stores it as a graphic file. This value is expressed in 256 grey colour shades. The processing of the obtained results consists in the mathematical transformation of the shadow vertical projections into a series of horizontal sections of the object which are suitable for creating three-dimensional images of the sample. 


\section{Relationship between petrographical properties and the crushability and grindability}

A thoroughgoing knowledge of the mineralogical assembly of the processed material is essential if efficient processing is to be carried out [9]. Not only the knowledge of the nature of minerals, or in case of the ores the valuable and gangue minerals, but also the size, the dissemination, association and shapes of minerals are important. Texture characterisation is usually subjective and traditionally more related to ore deposit exploration than to mineral processing performance [19]. All textures, including crystallinity, grain boundary relations, grain orientations, fractures, veinlets, etc. have a bearing on processing materials and ores, but the sizes of mineral grains and bonding between the grains are the main characteristics that influence ore breakage and mineral liberations [11]. In addition to these features, Comakli and Cayiril [20] emphasize the effect of the proportion of grains and matrix.

The relationships between petrographical and mechanical properties of rocks have been investigated in several studies $[2,3,21,22,23,24]$. The rock mechanics and crushability tests are frequently used in the simulation and modelling of the processes occurring in the comminution equipment, and they can be used in the studies of the relationship between rock properties and grindability [25]. The mechanical properties of rocks are influenced by numerous factors, the grain size is one of them. Öztürk et al. [26] and Esmailzadeh et al. [16] established that there is a positive correlation between the TC value and the uniaxial compressive strength (UCS), and the TC value and the point load index. Further positive correlation was found between the porosity and TC value, this can be explained by the fact that elongated grains propagate greater porosity and thus greater TC value. A decrease in the grain size results in an increase of the specific surface which leads to the increase of cohesiveness of the microstructure, finegrained rocks therefore always manifest greater strength than medium and coarse-grained types [2].

Researchers have diverse opinion about the impact of different textural elements on the grindability. Pérez-Barnuevo et al. [19] highlight that three textural features appear as the most significant for mineral liberation characterisation: grain size, grain boundary irregularity and the pattern of intergrowth type. Grain boundary irregularities provide a measure of the extent of intergrowth of minerals. Sinuous grain boundaries are usually accompanied by secondary minerals resulted by recrystallization and show strong intergrowths and a strong bond, whereas straight grain boundaries show no intergrowths and a weak bond [11]. Throughout rock breakage, the first breakage appears along existing fractures and voids. In the next phase, breakage occurs along the boundaries of weakly bonded grains. The components with strong bonds tend to break in random breakage across grain boundaries. Fractures generally initiate between two minerals with very different Young's modulus and Poisson's ratio. With the development of microcracks, the heterogeneity and anisotropy of rock gradually increases which leads to complex and unpredictable mechanical behaviour [4]. Wang [23] has demonstrated that the mineral distributions play a very important role in the breakage pattern. Breakage results depend on the proportion of minerals, especially the softest mineral. A hard mineral with a higher tensile strength absorbs energy more easily to form elastic deformation, whereas for a soft mineral with a lower tensile strength it is easier to absorb the energy to produce cracks.

Several authors have investigated the relationship between the Bond-work index $\left(\mathrm{W}_{\mathrm{i}, \mathrm{B}}\right)$ and the rock texture. Abdelhaffez [22] has reported that the overall mineralogy itself has little effect on the $\mathrm{W}_{\mathrm{i}, \mathrm{B}}$. The presence of secondary sulphate minerals, the difference in the hardness of the sulphate minerals, but mostly the degree of cohesion of the ore minerals with the enclosing gangue minerals and the variation in the composition of the gangue minerals plays an important factor in the mineral processing. The effect of minerals with different hardness on the grindability has been investigated by Csőke et al. [27], Gregus et al. [28]. Based on their research, the mineral with lower hardness tends to enrich in the product. This 
can be explained by the higher grinding velocity of the softer mineral and by the grinding effect of the harder mineral. The ratio of the minerals with different hardness also has an important effect on the grindability.

Yüce [29] has reported similar findings on the effect of the hardness of gangue minerals on the $\mathrm{W}_{\mathrm{i}, \mathrm{B}}$ emphasising that the alteration and the presence of cracks and fracture greatly attenuate the $\mathrm{W}_{\mathrm{i}, \mathrm{B}}$. This is in accordance with the findings of Yildirim [4] who made a detailed investigation, comparing the mineralogy of the unaltered and altered zones within the same ore body, determining the degree of alteration by defining the mineral substitution and the degradation of texture. According to his results, the altered rocks presented a lower $\mathrm{W}_{\mathrm{i}, \mathrm{B}}$ than those unaltered. Oyarzun and Arévalo [30] have concluded that the rocks with similar mineralogy have different Bond-work indices, thus a clear relationship between mineral content and $\mathrm{W}_{\mathrm{i}, \mathrm{B}}$ cannot be drawn, but $\mathrm{W}_{\mathrm{i}, \mathrm{B}}$ is greatly affected by the texture. They investigated four different rock types, latite porphyry, dacite porphyry, gabbro and tonalite. The two porphyries with similar chemical and mineralogical composition presented very different $\mathrm{W}_{\mathrm{i}, \mathrm{B}}$, while the gabbro and tonalite, which had different mineralogy but similar texture, presented similar $\mathrm{W}_{\mathrm{i}, \mathrm{B}}$ values. Congruent findings were reported by Kekec et al. [13]: the mineral content has no significant effect on the grindability, while the texture influences the crushing and the grindability of the rocks with similar formation. They also investigated the relationship between the parameters defining the texture such as the AGSI and the grindability rate, particle size distribution and the shape and volume factors of the product. The texture of the rocks does not have a significant effect on the shape and volume factors while it is greatly influenced by density and porosity. The grindability rate is influenced by texture in the case of rocks with similar formation. The mineral contents of the samples have no significant effect on the distribution of particle size discharged from the crusher and on the grindability rate.

\section{Summary}

The effect of texture on the grindability of rocks has been identified by numerous authors. Researches related to the topic are becoming even more widespread partially as a result of the efforts to understand and improve the energy efficiency of the processing operations [1]. These resulted in efforts to elaborate models with the aid of which based on the geological data certain features of processing can be prognosticated.

The descriptive nature of textural information can make it difficult to quantify and establish which textural attributes can be attributed to certain mineral processing behaviours [8], which is further compounded by the lack of a coherent definition for the term "texture".

A correlation, which can attribute numerical crushability and grindability values to certain textural features have not been established yet, however some general conclusions can be drawn. The effect of the mineralogical constitution is negligible, however the hardness, and the variation in hardness of different minerals have a great impact on the grindability. In the case of rocks with similar mineralogical constituent, the texture has a significant influence on the grindability. The decrease in grain size results in the increase of the specific surface which leads to the increase of cohesiveness. The particle shape and the grain boundary type have an influence on the grindability, greater boundary irregularity results in stronger interparticle bonds. The presence of alteration zones, faults and cracks also have an impact on the grindability. 


\section{Acknowledgements}

The author kindly appreciates the help of Dr. Rácz Ádám and Prof. Dr. habil Mucsi Gábor for their guidance, and useful critiques of this research work. The described article/presentation/study was carried out as part of the EFOP-3.6.1-16-2016-00011 "Younger and Renewing University Innovative Knowledge City - institutional development of the University of Miskolc aiming at intelligent specialisation" project implemented in the framework of the Szechenyi 2020 program. The realization of this project is supported by the European Union, co-fi-nanced by the European Social Fund.

\section{References}

[1] Napier-Munn, T.J., Drinkwater, D., Ballantyne G.: (2012) The CEEC Roadmap for Eco-Efficient Comminution, 2012 Workshop 12-13 June 2012, Noosa, Queensland, pp. 15,

[2] Popov, O., Talovina, I., Lieberwirth, H., Duriagina, A.: Quantitative Microstructural Analysis and X-ray Computed Tomography of Ores and Rocks-Comparison of Results, Minerals 2020, 10(129): 1-19. https://doi.org/10.3390/min10020129

[3] Korman, T., Bedekovic, G., Kujundzic, T., Kuhinek, D.: Impact of physical and mechanical properties of rocks on energy consumption of jaw crusher, Physicochem. Probl. Miner. Process 2015, 51(2): 461-475. https://doi.org/10.5277/ppmp150208

[4] Yildirim, B. G.: Development of a correlation between mineralogy, rock strength measures, and breakage of Copper Porphyries, $\mathrm{PhD}$ thesis, The University of Queensland (2016)

[5] Lamberg, P.: Particles-the bridge between geology and metallurgy, Conference in minerals engineering. Luleå (2011), pp.1-16.

[6] Ural, S., Akyildiz, M.: Studies of the relationship between mineral matter and grinding properties for low-rank coals, International Journal of Coal Geology 2004, 60: 81-84. https://doi.org/10.1016/j.coal.2004.07.001

[7] Lund, C., Lamberg, P., Lindberg, T.: A new method to quantify mineral textures for geometallurgy, Proceedings of Process Mineralogy (2014). pp. 1-30

[8] Bonnici, N.K.: The mineralogical and textural characteristics of copper-gold deposits related to mineral processing attributes, $\mathrm{PhD}$ thesis, School of Earth Sciences, University of Tasmania (2012), p. 281

[9] Wills, B.A., Napier-Munn T.J.: (2006) Mineral processing technology, 7th edition, Elsevier, 2006, ISBN 0750644508

[10] Hilden, M.M., Powell, M.S.: A geometrical texture model for multi-mineral liberation prediction, Minerals Engineering 2017, 111: 25-35. https://doi.org/10.1016/j.mineng.2017.04.020

[11] Petruk, W.: Applied mineralogy in the mining industry, Elsevier, Amsterdam, 2000, ISBN 0444 500774

[12] Dominy, C. S., O`Connor, L., Parbhakar-Fox, A., Glass, J. H., Purevgerel S.: Geometallurgy-A route to more resilient mine operations, Minerals 2018, 8(12): 560. https://doi.org/10.3390/MIN8120560

[13] Kekec, B., Unal, M., Sensogut, M.: Effect of the textural properties of rocks on their crushing and grinding features, Journal of University of Science and Technology Beijing, Volume 13, Number 5, October 2006, pp. 385-392. https://doi.org/10.1016/S1005-8850(06)60079-0

[14] Hesse, M., Popov, O., Lieberwirth, H.: Increasing efficiency by selective comminution, Minerals Engineering 2017 103-104: 112-126. https://doi.org/10.1016/J.MINENG.2016.09.003 
[15] Howarth, D.F., Rowlands, J.C.: Quantitative assessment of rock texture and correlation with drillability and strength properties. Rock Mech. Rock Engng. 1987, 20: 57-85. https://doi.org/1007/BF01019511

[16] Esmailzadeh, A., Behnam, S., Mikaeil, R., Naghadehi, M. Z., Saei, S.: Relationship between Texture and Uniaxial Compressive Strength of Rocks, Civil Engineering Journal 2017, 3(7): 480-486. https://doi.org/10.28991/CEJ-2017-00000106

[17] Warlo, M., Wanhainen, C., Bark, G., Butcher, R. A., McElroy, I., Brising, D., Rollinson, K. G.: Automated Quantitative Mineralogy Optimized for Simultaneous Detection of (Precious/Critical) Rare Metals and Base Metals in A Production-Focused Environment, Minerals 2019, 9: 440. https://doi.org/3390/MIN9070440

[18] Goodall R. W., Scales J. P., Butcher, R. A.: The use of QEMSCAN and diagnostic leaching in the characterisation of visible gold in complex ores, Minerals Engineering 2005, 18: 877-886. https://doi.org/10.1016/J.MINENG.2005.01.018

[19] Pérez-Barnuevo, L., Pirard, E., Castroviejo, R.: Automated characterization of intergrowth texture in mineral particles. A case study, Minerals Engineering 2013, 52: 136-142. https://doi.org/10.1016/J.MINENG.2013.05.001

[20] Comakli, R., Cayirli, S. A correlative study on textural properties and crushability of rocks, Bulletin of Engineering Geology and the Environment 2019, 78: 3541-3557. https://doi.org/10.1007/s10064-018-1357-8

[21] Cai, M., Kaiser, P.K., Tasaka, Y., Minami, M.: Peak and residual strengths of jointed rock masses and their determination for engineering design. 1st Canada-U.S. Rock Mech. Symp. (2007), pp. 259-267, https://doi.org/10.1201/noe0415444019-c32

[22] Abdelhaffez G. S.: Studying the effect of ore texture on the Bond Work Index at the Mahd Ad Dahab Gold Mine: a case study, Rudarsko Geolosko Naftni Zbornik 2020, 35(1): 111-121. https://doi.org/10.17794/rgn.2020.1.9

[23] Wang, Y.: Numerical modelling of heterogeneous rock breakage behaviour based on texture images, Minerals Engineering 2015, 74: 130-141. https://doi.org/10.1016/J.MINENG.2014.12.030

[24] Tøgersen, M.K., Kleiv, R.A., Ellefmo, S., Aasly, K.: Mineralogy and texture of the Storforshei iron formation, and their effect on grindability, Minerals Engineering 2018, 125: 176-189. https://doi.org/10.1016/J.MINENG.2018.06.009

[25] Lois-Morales, P., Evans, C., Bonfils, B., Weatherley, D.: The impact load cell as a tool to link comminution properties to geomechanical properties of rocks, Minerals Engineering 2020, 148. https://doi.org/10.1016/j.mineng.2020.106210

[26] Öztürk A., Nasuf E., Bilgin N.: The assessment of rock cutability, and physical and mechanical rock properties from a texture coefficient, The Journal of The South African Institute of Mining and Metallurgy 2004: 397-402.

[27] Csőke, B., Rácz, Á., Mucsi, G.: Determination of the Bond work index of binary mixtures by different methods, International Journal of Mineral Processing 2013, 123: 78-86. https://doi.org/10.1016/j.minpro.2013.05.004 
[28] Gregus, É., Rácz, Á., Csőke, B.: Eltérő őrölhetőségü anyagok együttőrlésének alapvizsgálata univerzális Hardgrove malomban, Építőanyag- Journal of Silicate Based and Composite Materials 2018, 70(3): 90-96. https://doi.org/10.14382/epitoanyag-jsbcm.2018.17

[29] Yüce, A.E.: Grinding size estimation and beneficiation studies based on simple properties of ore components, Physicochem. Probl. Miner. Process. 2017, 53(1): 541-552. http://dx.doi.org/10.5277/ppmp170142

[30] Oyarzún, M., Arévalo, A.: Rock Texture and BWi Relationships, El Teniente Ore Deposit, Chile; The First Ausim International Geometallurgy Conference, 5-7 September 2011 Brisbane, Australia, pp. 181-186 